\title{
Anaerobes and Gardnerella vaginalis in non-specific vaginitis
}

\author{
LESLIE V H HILL \\ From the Department of Genitourinary Medicine, James Pringle House, Middlesex Hospital, \\ London WIN 8AA
}

SUMMARY Clinical evidence of bacterial vaginosis was present in $25(35 \%)$ of 72 patients attending a London venereology clinic and correlated significantly with abnormal organic acids in vaginal secretions $(24 / 25)$, with Gardnerella vaginalis on culture $(17 / 25)$, with complaints of vaginal malodour $(15 / 25)$, and with a relative scarcity of white blood cells in vaginal secretions. Anaerobic vaginal flora were presumptively identified by gas-liquid chromatographic analysis of organic acids found in vaginal secretions. The clinical criteria used to diagnose bacterial vaginosis included the presence of at least three of the four following characteristics: (a) a vaginal $\mathrm{pH} \geqslant 4 \cdot 5$, vaginal secretions that (b) were homogeneous, (c) contained "clue" cells, and (d) released a "fishy" amine odour when mixed with $10 \%$ potassium hydroxide. Because 17 of the 25 patients with clinical bacterial vaginosis had both chromatographic bacterial vaginosis and $G$ vaginalis, causative organisms were difficult to identify. None of the six patients who had $G$ vaginalis but not chromatographic bacterial vaginosis had clinical bacterial vaginosis, but seven of the 10 women with chromatographic bacterial vaginosis but not $G$ vaginalis had clinical bacterial vaginosis $\left(p<0.02, \chi^{2}\right.$ with Yates's correction). This finding supports the recent suggestions that anaerobes are important in the production of clinical signs of bacterial vaginosis.

\section{Introduction}

Although vaginitis caused by yeasts or by Trichomonas vaginalis has been well described and documented, other forms continue to present diagnostic challenges to both doctors and researchers. These other forms have been lumped into the category commonly known as non-specific vaginitis (NSV). This designation, however, has not helped doctors attempting to treat an infection possibly caused by one or many micro-organisms.

To clarify the diagnostic confusion, Gardner and Dukes suggested 30 years ago that the vast majority of cases of NSV were caused by Haemophilus vaginalis (Corynebacterium vaginale), ${ }^{1}$ which is currently known as Gardnerella vaginalis, ${ }^{2}$ explaining that women with a grey, homogeneous, odorous discharge with a pH of 5.0 to 5.5 that yields no trichomonads probably have $H$ vaginalis vaginitis.

More recently Pheifer et al noted that vaginal secretions from women with NSV that had those

Address for reprints: Dr L V H Hill, Infectious Disease Research Laboratory, Izaak Walton Killam Hospital for Children, 5850 University Ávenue, Halifax, Nova Scotia B3J 3G9, Canada

Accepted for publication 8 June 1984 clinical characteristics liberated an amine odour with, and often without, the addition of $10 \%$ potassium hydroxide. ${ }^{3}$ They also noted an increased concentration of anaerobes in these abnormal secretions. Chen et al showed that the distinctive odour was due to volatilisation of polyamines, particularly putrescine and cadaverine, produced by vaginal anaerobic

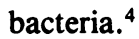

Practical diagnostic criteria for standard clinical use have been proposed by Amsel et $a l^{5}$ who suggested that patients should be considered to have a specific kind of NSV if they have at least three of four characteristics: (a) a vaginal $\mathrm{pH}$ of more than 4.5 and vaginal secretions that (b) were homogeneous, (c) contained "clue" cells, and (d) released a "fishy" amine odour when mixed with $10 \%$ potassium hydroxide.

The term bacterial vaginosis has been proposed to define NSV of bacterial origin, ${ }^{6}$ and is used with that meaning in this report. For the purposes of this investigation it was assumed that bacterial vaginosis may occur with or without concurrent protozoan or fungal vaginal infections. Cases of trichomoniasis or candidosis are therefore not excluded or dealt with separately from those of bacterial vaginosis.

This study correlated the clinical signs of bacterial 
vaginosis with the presence of $G$ vaginalis and vaginal anaerobic bacteria, which were presumptively identified by the pattern of organic acids noted on gas-liquid chromatography of vaginal secretions. ${ }^{7}$ It assessed what subjective symptoms of vaginitis, if any, were associated with the objective clinical signs of bacterial vaginosis, and studied the inflammatory response produced by bacterial vaginosis compared with other types of vaginitis.

\section{Patients and methods}

Seventy two women attending this clinic during May 1982 were examined for the presence of vaginal infections. The patients presented with a new problem, were not menstruating at the time of examination, and had not taken antibiotics during the month before their attendance. Any woman who fulfilled these criteria when the investigator was available was examined, and information on her medical background and current symptoms was recorded using a standardised questionnaire.

Each patient underwent a complete pelvic examination, during which the clinical findings were recorded on a standard form. Cervical samples for the isolation of Neisseria gonorrhoeae ${ }^{8}$ and vaginal samples for the isolation of $T$ vaginalis $^{9}$ and vaginal yeasts (grown on Sabouraud's agar) ${ }^{10}$ were collected from each patient. In addition, a swab from the posterior fornix was taken and sent to the laboratory in Amies modification of Stuart's transport medium for culture for $G$ vaginalis. The vaginal $\mathrm{pH}$ was measured with $\mathrm{pH}$ indicator paper (Whatman Filter Paper, N/Range, 4/6; Scientific Supplies Co Ltd, London) applied direct to the vaginal walls by means of sponge forceps.

Vaginal secretions were collected by instilling $3 \mathrm{ml}$ of sterile distilled water into the vagina, using a plastic syringe. A sterile cotton swab was then used to wipe discharge from the vaginal walls into a pool in the posterior fornix, where the discharge was mixed with the water (taking care to avoid cervical secretions). The mixture of water and vaginal discharge was then pipetted into a screw topped glass vial.

A drop from each of the vaginal secretions collected was examined microscopically to estimate the number of white blood cells and for the presence of $T$ vaginalis, "clue" cells, a "fishy" odour on adding $10 \%$ postassium hydroxide, and fungal filaments or buds. Bacterial vaginosis was diagnosed using the criteria of Amsel et al, ${ }^{5}$ except that a vaginal $\mathrm{pH}$ of $\geqslant 4.5$ rather than $>4 \cdot 5$ was used. After microscopical examination, the vaginal secretions were stored at $-20^{\circ} \mathrm{C}$.
Swabs from the posterior fornix were examined by standard microbiological methods in the microbiology laboratory of this hospital. Plates of purple agar base (Difco, East Molesey, Surrey, UK) containing bromocresol purple, naladixic acid, and colistin were inoculated with the swabs taken from the posterior fornix for identification of $G$ vaginalis. After $50 \mu \mathrm{g}$ metronidazole discs had been applied to their inoculated surfaces, plates were incubated at $37^{\circ} \mathrm{C}$ for 48 hours in anaerobic gas pac jars (BBL; Becton Dickinson and Co, Cockeysville, Maryland, USA). Gram stained smears of each swab were prepared and examined for the presence of $G$ vaginalis (small pleomorphic, Gram variable bacilli, often in solid fields) ${ }^{2}$ and for "clue" cells associated with $G$ vaginalis (epithelial cells in varying degrees of disintegration, with indefinite outlines and granular looking cytoplasm). ${ }^{1}$ Plates with characteristic colonial morphology that gave negative results for catalase and $1 \%$ potassium tellurite were reported as giving positive cultures. ${ }^{11}$ (Although more sensitive methods have been reported, we were unable to carry the identification further routinely in this centre.) Inhibition of growth by metronidazole was noted.

A Pye Unicam Series 204 gas-liquid chromatograph equipped with a flame ionisation detector was used to analyse vaginal wash samples. The column was packed with Carbowax 20 mol/l TPA (tannic, polyphosphomolybolic, and amido acid) on AW.DMCS Chromosorb G, 80-100 mesh. A flame ionisation detector using air, hydrogen, and nitrogen in a $2 \cdot 2 \mathrm{~m}$ $(6 \mathrm{ft})$ column at $20 \mathrm{ml} /$ minute was used. Samples were run at $145^{\circ} \mathrm{C}$ to extract volatile fatty acids and at $135^{\circ} \mathrm{C}$ to extract non-volatile fatty acids.

To extract volatile fatty acids from the vaginal secretions I pipetted $1 \mathrm{ml}$ into a rubber stoppered tube and added three or four drops of $50 \%$ sulphuric acid followed by $1 \mathrm{ml}$ of diethyl ether. The solution was mixed by gently inverting the tubes 20 times. The mixture was centrifuged sufficiently to break up the emulsion of ether and aqueous medium, and $1 \mu \mathrm{l}$ of the top (ether) layer was injected into the column.

To extract non-volatile fatty acids from the vaginal secretions I pipetted $1 \mathrm{ml}$ into a screw topped glass vial and added $2 \mathrm{ml}$ of methanol and $0.4 \mathrm{ml}$ of $50 \%$ sulphuric acid. The solution was heated in a water bath at $56^{\circ} \mathrm{C}$ for 30 minutes, after which $1 \mathrm{ml}$ of water and $0.5 \mathrm{ml}$ of chloroform were added. The mixture was centrifuged sufficiently to break up the emulsion of chloroform and aqueous medium, and $1 \mu \mathrm{l}$ of the bottom (chloroform) layer was injected into the column.

A chromatographic diagnosis of bacterial vaginosis was made if propionate, isobutyrate, butyrate, or isovalerate was found or the ratio of succinate to lactate was $\geqslant 0 \cdot 4$, or both. ${ }^{7}$ 
Data were analysed using the $\chi^{2}$ test with Yates's correction $\left(\chi_{c}^{2}\right)$ as numbers were less than 100 $(n=72)$ and some values in $2 \times 2$ tables were less than 10 .

\section{Results}

Of the 72 patients studied, $64(89 \%)$ were white and $55(76 \%)$ were aged 16-30. Most presented with complaints of vaginal discharge (24) or a suspected sexually transmitted disease (21), 10 complained chiefly of vulval irritation, while the remaining 17 women had other presenting problems. Seventeen patients $(24 \%)$ were found to have yeast vaginitis, three harboured $T$ vaginalis, and three $N$ gonorrhoeae. Cervicitis due to infection with Chlamydia trachomatis was not assessed.

Table I shows that chromatographic diagnoses of bacterial vaginosis and the presence of $G$ vaginalis on culture correlated with clinical diagnoses $\left(\chi^{2}{ }_{c}=45.9\right.$ and 16.3 respectively; $p<0.001$ for each). A diagnosis of bacterial vaginosis was suggested by chromatographic analysis of vaginal secretions in 29 $(40 \%)$ patients; $G$ vaginalis was isolated from 25 $(35 \%)$. Chromatographic diagnoses also strongly correlated with the presence of $G$ vaginalis on culture (19 out of 29 with chromatographic diagnoses versus 6 out of 43 with normal chromatography $\left.\left(\chi_{c}^{2}=18 \cdot 1 ; p<0 \cdot 001\right)\right)$.

TABLE I Correlation of clinical and laboratory (gas-liquid chromatographic) diagnoses of bacterial vaginosis and results of culture for Gardnerella vaginalis

\begin{tabular}{|c|c|c|}
\hline & \multicolumn{2}{|c|}{ Clinical diagnoses } \\
\hline & $\begin{array}{l}\text { Positive } \\
(n=25)\end{array}$ & $\begin{array}{l}\text { Negative } \\
(n=47)\end{array}$ \\
\hline \multicolumn{3}{|c|}{ Chromatographic diagnoses: } \\
\hline Positive & 24 & 5 \\
\hline Negative & 1 & 42 \\
\hline \multicolumn{3}{|c|}{$G$ vaginalis on culture: } \\
\hline Present & 17 & 8 \\
\hline Absent & 8 & 39 \\
\hline
\end{tabular}

Although 25 patients had clinical bacterial vaginosis, $17(68 \%)$ of them had both chromatographic bacterial vaginosis and $G$ vaginalis, which made it difficult to assess causative organisms. Table II shows that none of the six patients with $G$ vaginalis but not chromatographic bacterial vaginosis had clinical bacterial vaginosis, although seven of the 10 patients with chromatographic bacterial vaginosis but not $G$ vaginalis had clinical bacterial vaginosis $\left(\chi_{c}^{2}=4 \cdot 89, p<0 \cdot 02\right)$.
TABLE II Correlation of clinically diagnosed bacterial vaginosis with positive cultures of Gardnerella vaginalis and with gas-liquid chromatographic analysis of organic acids in vaginal secretions

\begin{tabular}{lcc}
\hline & \multicolumn{2}{l}{ Clinical diagnoses } \\
\cline { 2 - 3 } & $\begin{array}{l}\text { Positive } \\
(n=25)\end{array}$ & $\begin{array}{l}\text { Negative } \\
(n=47)\end{array}$ \\
\hline $\begin{array}{l}\text { G vaginalis present only } \\
\text { Chromatographic diagnoses }\end{array}$ & 0 & 6 \\
$\begin{array}{l}\text { positive only } \\
\text { Noth }\end{array}$ & $7(28 \%)$ & 3 \\
Neither & $17(68 \%)$ & 2 \\
\hline
\end{tabular}

Comparing positive chromatographic diagnoses only with $G$ vaginalis present only, $\mathrm{p}<0.02$ ( $\chi^{2}$ test with Yates's correction).

Table III shows that "clue" cells seen on the wet preparation of vaginal secretions significantly correlated both with the isolation of $G$ vaginalis and with abnormal chromatographs $\left(\chi^{2}{ }_{c}=15.60\right.$ and 36.29 respectively, $p<0.001$ for each). Hospital laboratory reports of "clue" cells seen in Gram stained smears of vaginal swabs also correlated significantly with the growth of $G$ vaginalis on culture (18/25 versus $2 / 47)$ and with chromatographic bacterial vaginosis $(19 / 29$ versus $1 / 43)$ $\left(\chi_{c}^{2}=34.03\right.$ and 31.40 respectively, $p<0.001$ for each). The finding of "clue" cells in wet preparations correlated significantly with "clue" cells in Gram stained smears $\left.\chi_{c}^{2}=27 \cdot 53, p<0.001\right)$.

I compared symptoms in patients with a single type of vaginitis, patients with more than one type of vaginitis, and patients who did not have vaginitis. The types of vaginitis showed no distinct patterns of symptoms. Table IV supports the relative absence of irritative symptoms in clinical bacterial vaginosis by showing microscopical findings of reduced numbers of white blood cells in the vaginal secretions of patients with $G$ vaginalis or chromatographic

TABLE III Correlation of "clue" cells in wet preparations with those in Gram stained smears, with Gardnerella vaginalis on culture, and with chromatographic diagnoses of bacterial vaginosis

\begin{tabular}{llc}
\hline & \multicolumn{2}{l}{ Clue cells in normal saline } \\
\cline { 2 - 3 } & $\begin{array}{l}\text { Present } \\
(n=28)\end{array}$ & $\begin{array}{c}\text { Absent } \\
(n=44)\end{array}$ \\
\hline Clue cells in Gram smears: & 18 & 2 \\
$\quad \begin{array}{l}\text { Present } \\
\text { Absent }\end{array}$ & 10 & 42 \\
$\begin{array}{l}\text { vaginalis on culture: } \\
\text { Present }\end{array}$ & 18 & 7 \\
$\quad$ Absent & 10 & 37 \\
Chromatographic diagnoses: & & \\
$\quad$ Positive & 24 & 5 \\
Negative & 4 & 39 \\
\hline
\end{tabular}


bacterial vaginosis only compared with the inflammatory response seen in the vaginal secretions of those with $T$ vaginalis, $N$ gonorrhoeae, or candidosis only.

TABLE IV Comparison of white blood count (WBC) with type of infection present on culture of vaginal secretions from 45 patients*

\begin{tabular}{lcll}
\hline $\begin{array}{l}\text { WBC/high } \\
\text { power field }\end{array}$ & $\begin{array}{l}\text { Culture } \\
\text { negative } \\
(n=25)\end{array}$ & $\begin{array}{l}\text { Trichomonas, } \\
\text { N gonorrhoeae, } \\
\text { or yeast only } \\
(n=11)\end{array}$ & $\begin{array}{l}\text { G vaginalis } \\
\text { or abnormal } \\
(n C \text { only } \\
(n=9)\end{array}$ \\
\hline None & 5 & 1 & 2 \\
$1-10$ & 12 & 2 & 4 \\
$10-50$ & 7 & 5 & 2 \\
$>50$ & 1 & 3 & 1 \\
\hline
\end{tabular}

* Chlamydia trachomatis not assessed; 27 patients with mixed infections not included. GLC = gas-liquid chromatography.

Table $\mathrm{V}$ shows the presence of cervical or vaginal infections among women with clinical or chromatographic bacterial vaginosis. Most of the women with $G$ vaginalis or $T$ vaginalis were diagnosed clinically and on chromatographic grounds as having bacterial vaginosis. No appreciable correlations were found between the presence of clinical or chromatographic bacterial vaginosis and the isolation of $N$ gonorrhoeae, $T$ vaginalis, or vaginal yeasts, which supports the argument that bacterial vaginosis may occur with, as well as in the absence of, these infections.

TABLE V Prevalence of bacterial vaginosis in various groups of patients

\begin{tabular}{llc}
\hline & \multicolumn{2}{l}{$\begin{array}{l}\text { No (\%) with } \\
\text { bacterial vaginosis: }\end{array}$} \\
\cline { 2 - 3 } Positive on culture (or $G L C)$ & Clinically & On GLC \\
\hline$N$ gonorrhoeae on culture $(\mathrm{n}=3)$ & $1(33)$ & $1(33)$ \\
$T$ vaginalis on culture $(\mathrm{n}=4)$ & $3(75)$ & $3(75)$ \\
Vaginal yeasts on culture $(\mathrm{n}=17)$ & $5(29)$ & $5(29)$ \\
$G$ vaginalis on culture $(\mathrm{n}=25)$ & $17(68)$ & $14(56)$ \\
Bacterial vaginosis on GLC $(\mathrm{n}=29)$ & $24(83)$ & $29(100)$ \\
\hline
\end{tabular}

*GLC = gas-liquid chromatography.

Raised acetate concentrations in vaginal secretions are probably related to carriage of $G$ vaginalis. Table VI shows that the organic acid found most commonly on chromatographic analysis of vaginal washings from the 72 women studied was acetate $(88 \%)$. Although only $41 \%$ of patients with acetate had clinical signs of bacterial vaginosis, $66 \%(31 / 47)$ of patients with clinical bacterial vaginosis had larger acetate peaks ( $>2 \mathrm{~mm}$ high), and $85 \%(40 / 47)$ of those without clinical bacterial vaginosis had small acetate peaks $(<2 \mathrm{~mm}$ high). Lactate peaks were found in $79 \%(57 / 72)$ of all patients, only one third of whom had clinical bacterial vaginosis. Succinate was found commonly in patients with and without clinical bacterial vaginosis. Of women with a ratio of succinate to lactate peaks of $\geqslant 0.4,92 \%(22 / 24)$ had clinical bacterial vaginosis. All those with propionate and butyrate, seven out of eight with isovalerate, and all four with succinate but without lactate had clinical bacterial vaginosis. Abnormal organic acids were present in vaginal secretions in $96 \%(24 / 25)$ of women with clinical bacterial vaginosis, as opposed to only $11 \%(5 / 47)$ of those without it (table I).

TABLE VI Prevalence of organic acids in vaginal washes from 72 patients

\begin{tabular}{lll}
\hline Type of acid & No (\%) positive & $\begin{array}{l}\text { No (\%) with clinical } \\
\text { bacterial vaginosis }\end{array}$ \\
\hline Acetate (A) & $63(88)$ & $26(41)$ \\
A $>2$ mm & $28(39)$ & $22(79)$ \\
Lactate (L) & $57(79)$ & $19(33)$ \\
Succinate (S) & $50(69)$ & $24(48)$ \\
S/L ratio >0.4 & $24(33)$ & $22(92)$ \\
Propionate & $19(26)$ & $19(100)$ \\
Butyrate & $15(21)$ & $15(100)$ \\
Isovalerate & $8(11)$ & $7(88)$ \\
\hline
\end{tabular}

\section{Discussion}

The word "non-specific" in its name suggests that the causes, diagnosis, and treatment of NSV are poorly understood. In this study, characteristic clinical signs $s^{5}$ and organic acids in vaginal secretions ${ }^{7}$ provided specific clinical and chromatographic diagnostic criteria.

Results of this study confirmed recent suggestions that anaerobes may be important in the production of bacterial vaginosis. ${ }^{3-7}$ Chromatography can be used to give a rapid laboratory diagnosis of bacterial vaginosis by measuring directly the characteristic organic acids in vaginal secretions produced by bacteria capable of causing bacterial vaginosis. This study confirmed the chromatographic criteria of Speigel et $a l^{7}$ which correlated significantly with both clinical diagnoses and with the presence of $G$ vaginalis. Such findings support the notion that both $G$ vaginalis and vaginal anaerobes are commonly associated with clinical signs of bacterial vaginosis (table I).

Twenty five (35\%) patients had clinical bacterial vaginosis, but because $17(68 \%)$ of them had both chromatographic bacterial vaginosis and $G$ vaginalis it was difficult to assess causative organisms. None of the six patients with $G$ vaginalis but without chromatographic bacterial vaginosis had clinical bacterial vaginosis, although seven of the 10 patients 
with chromatographic bacterial vaginosis in the absence of $G$ vaginalis had clinical bacterial vaginosis (although the numbers used are small, $\chi^{2}$ with Yates's correction $=4 \cdot 89, \mathrm{p}<0.02)$ (table II). This finding supports suggestions that anaerobic bacteria are important in the production of clinical signs of bacterial vaginosis.

The symptom correlating best with a clinical diagnosis of bacterial vaginosis was found to be vaginal malodour. Most clinic patients complained of excessive vaginal discharge, malodour, or vulval irritation. Symptoms of vaginitis, however, have been shown to be poor indicators of actual vaginal infections. ${ }^{12}$ Objective clinical signs were therefore used to diagnose bacterial vaginosis. All women studied were examined for the presence of vaginal yeasts, $T$ vaginalis, $N$ gonorrhoeae, $G$ vaginalis, and organic acids produced by vaginal bacteria. Cultures for $C$ trachomatis were not available for all clinic patients included in the study, and infection with this micro-organism may have been responsible for some of the unexplained symptoms of abnormal vaginal discharge. ${ }^{13}$

"Clue" cells seen on both wet preparations and Gram stained smears were significantly associated with the isolation of $G$ vaginalis on culture and with the presumptive diagnosis of vaginal anaerobic bacteria made by chromatography of vaginal secretions. This finding suggests that Gram staining of secretions is not necessary when looking for "clue" cells (table III).

The non-inflammatory nature of bacterial vaginosis was first described by Gardner and Dukes, who reported that white blood cells were not a prominent finding in vaginal secretions of women with $G$ vaginalis infections. ${ }^{1}$ When at least three of the four signs of bacterial vaginosis were present I found few white blood cells in vaginal secretions (table IV), a finding that applied to women with abnormal chromatographic patterns as well as to those with positive $G$ vaginalis cultures.

The sensitivity of the gas-liquid chromatograph equipped with a flame ionisation detector in confirming clinical diagnoses of bacterial vaginosis was $96 \%$; the specificity was $89 \%$; and the predictive value was $83 \%$. These results (table VI) were much better than those obtained in a previous study using a chromatograph equipped with a relatively less sensitive detector of thermal conductivity. ${ }^{14}$

Anaerobic bacteria are normally present in vaginal flora. ${ }^{15}$ The abnormal chromatographic patterns associated with bacterial vaginosis, however, suggest either the presence of new anaerobic bacteria or the overgrowth of existing species. $G$ vaginalis existed alone in six patients in this study without apparent clinical effect on any of them. $G$ vaginalis may simply act as a marker indicating the presence of abnormal vaginal anaerobes or vaginal anaerobic overgrowth, or it may act by altering vaginal conditions to enhance anaerobic growth. ${ }^{4}$

Metronidazole $500 \mathrm{mg}$ twice daily for seven days is currently the most effective treatment of bacterial vaginosis. ${ }^{3716}$ Its therapeutic efficacy may be due to its inhibition of vaginal anaerobes, rather than of $G$ vaginalis, which would further support the role of anaerobic bacteria in bacterial vaginosis. In vitro studies have shown $G$ vaginalis to be comparatively insensitive to metronidazole, ${ }^{16}$ whose hydroxy metabolite, however, has an appreciable effect on $G$ vaginalis. ${ }^{17}$

This investigation suggests the presence of anaerobes by showing abnormal organic acids in vaginal secretions in $96 \%(24 / 25)$ of clinical diagnoses of bacterial vaginosis. These findings support those of previous studies, which showed large numbers of anaerobic bacteria identified by species in women with clinical evidence of bacterial vaginosis. ${ }^{718}$

Detecting organic acids in vaginal secretions is a relatively new laboratory technique for the presumptive identification of anaerobes in vaginal flora. Results of chromatographic analyses of organic acids are more rapidly available than those of microbial culture. This newer laboratory method may thus be helpful in the rapid diagnosis of bacterial vaginosis. Many doctors do not have ready access to facilities for culture of $G$ vaginalis or to gas-liquid chromatography, in which case the four clinical characteristics can be assessed for diagnosis without the need for microbial culture or chromatography.

Bacterial vaginosis has been shown to be a discrete and easily diagnosed infection. Further studies are needed to investigate: the pathogenicity of $G$ vaginalis and its interactions with other vaginal bacteria, particularly anaerobes; the carriage of anaerobic bacteria and $G$ vaginalis in men; the sexual transmission of these organisms; and the treatment of infections with them in both sexes.

I thank Dr R D Catterall, Director of James Pringle House, Middlesex Hospital, London for allowing me to carry out this senior elective, and the medical staff for their invaluable assistance; Dr G L Ridgway, Director of University College Microbiology Laboratories, London, for provision of gas-liquid chromatography research facilities, and $\mathrm{Mr}$ Peter Luton for instruction in analysis of gas-liquid chromatography; and $\operatorname{Dr} \mathrm{J} A$ Embil of the Infectious Disease Research Laboratory, Izaak Walton Killam Hospital for Children, Halifax, Canada for support throughout the project. This work is a continuation of studies begun while I held a Dalhousie University Medical Research Foundation Studentship. 


\section{References}

1. Gardner HL, Dukes CD. Haemophilus vaginalis vaginitis: a newly defined specific infection previously classified "nonspecific" vaginitis. Am J Obstet Gynecol 1955; 69:962-6.

2. Greenwood JR, Pickett MJ. Transfer of Haemophilus vaginalis to a new genus, Gardnerella: $G$ vaginalis (Gardner and Dukes) comb. nov. International Journal of Systematic Bacteriology 1980; 30: 170-8.

3. Pheifer TA, Forsyth PS, Durfee MA, Pollock HM, Holmes KK. Nonspecific vaginitis: role of Haemophilus vaginalis and treatment with metronidazole. $N$ Engl J Med 1978;298: 1429-34.

4. Chen KCS, Forsyth PS, Buchanan TM, Holmes KK. Amine content of vaginal fluid from untreated and treated patients with nonspecific vaginitis. J Clin Invest 1979; 63:828-35.

5. Amsel R, Totten PA, Spiegel CA, Chen KC, Eschenbach D, Holmes KK. Nonspecific vaginitis. Diagnostic criteria and microbial and epidemiologic associations. $\mathrm{Am} \mathrm{J} \mathrm{Med}$ 1983; 74:14-22.

6. Spiegel CA, Davick $P$, Totten PA, et al. Gardnerella vaginalis and anaerobic bacteria in the etiology of bacterial (nonspecific) vaginosis. Scand J Infect Dis [Suppl] 1983;40:41-6.

7. Spiegel CA, Amsel R, Eschenbach D, Schoenknecht F, Holmes $\mathrm{KK}$. Anaerobic bacteria in nonspecific vaginitis. N Engl J Med 1980; 303:601-7.

8. Erdman YJ, Parry JM. Trimethoprim in a selective medium for isolation of gonococci. British Journal of Venereal Diseases 1981;57:348-9.
9. Bushby SRM, Copp FC. The antitrichomonal activity of amidonitrothiazoles. J Pharm Pharmacol 1955; 7:112-7.

10. Emmons CW, Binford CH, Utz JP, Kwon-Chung KJ. Medical mycology. 3rd ed. Philadelphia: Lea and Febiger, 1977.

11. Smith RF. New medium for isolation of Corynebacterium vaginale from genital specimens. Health Lab Sci 1975; 12:219-24.

12. McGuire LS, Guzinski GM, Holmes KK. Psychosexual functioning in symptomatic and asymptomatic women with and without signs of vaginitis. Am J Obstet Gynecol 1980; 137:600-3

13. Johannisson G, Lowhagen G-B, Lycke E. Genital Chlamydia trachomatis infection in women. Obstet Gynecol 1980;56:671-5.

14. Hill LH, Ruparelia H, Embil JA. Nonspecific vaginitis and other genital infections in three clinic populations. Sex Transm Dis 1983; 10: 114-8.

15. Larsen B, Galask RP. Vaginal microbial flora: practical and theoretic relevance. Obstet Gynecol 1980; 55: 100S-3S.

16. Balsdon MJ, Taylor GE, Pead L, Maskell R. Corynebacterium vaginale and vaginitis: a controlled trial of treatment. Lancet 1980; i: 501-3.

17. Ralph ED, Amatnieks YE. Relative susceptibilities of Gardnerella vaginalis (Haemophilus vaginalis), Neisseria gonorrhoeae, and Bacteroides fragilis to metronidazole and its two major metabolites. Sex Transm Dis 1980; 7:157-60.

18. Taylor E, Blackwell AL, Barlow D, Phillips I. Gardnerella vaginalis, anaerobes, and vaginal discharge. Lancet 1982; i: 1376-9. 